University of Nebraska - Lincoln

DigitalCommons@University of Nebraska - Lincoln

USGS Staff -- Published Research

US Geological Survey

2003

\title{
Evidence for disease-related amphibian decline in Colorado
}

Erin Muths

USGS-Biological Resources Division, muthse@usgs.gov

Paul Stephen Corn

bUSGS-Biological Resources Division

Allan P. Pessier

Zoological Society of San Diego

D. Earl Green

USGS-Biological Resources Division

Follow this and additional works at: https://digitalcommons.unl.edu/usgsstaffpub

Part of the Earth Sciences Commons

Muths, Erin; Corn, Paul Stephen; Pessier, Allan P.; and Green, D. Earl, "Evidence for disease-related amphibian decline in Colorado" (2003). USGS Staff -- Published Research. 130.

https://digitalcommons.unl.edu/usgsstaffpub/130

This Article is brought to you for free and open access by the US Geological Survey at DigitalCommons@University of Nebraska - Lincoln. It has been accepted for inclusion in USGS Staff -- Published Research by an authorized administrator of DigitalCommons@University of Nebraska - Lincoln. 


\title{
Evidence for disease-related amphibian decline in Colorado
}

\author{
Erin Muths ${ }^{\mathrm{a}, *}$, Paul Stephen Corn ${ }^{\mathrm{b}}$, Allan P. Pessier ${ }^{\mathrm{c}, 1}$, D. Earl Green ${ }^{\mathrm{d}}$ \\ ${ }^{a} U S G S$-Biological Resources Division, Fort Collins Science Center, 2150 Centre Avenue, Fort Collins, CO 80525, USA \\ ${ }^{\mathrm{b}} U S G S$-Biological Resources Division, Northern Rocky Mountain Research Center and Aldo Leopold Wilderness Research Center 790 E. Beckwith, \\ Missoula, MT 59807, USA \\ ${ }^{\mathrm{c}}$ Department of Pathology, Zoological Society of San Diego, PO Box 120551, San Diego, CA 92112-0551, USA \\ ${ }^{\mathrm{d}}$ USGS - Biological Resources Division, National Wildlife Health Center, 6006 Schroeder Road, Madison, WI 53711, USA
}

Received 31 October 2001; accepted 14 July 2002

\begin{abstract}
The recent discovery of a pathogenic fungus (Batrachochytrium dendrobatidis) associated with declines of frogs in the American and Australian tropics, suggests that at least the proximate cause, may be known for many previously unexplained amphibian declines. We have monitored boreal toads in Colorado since 1991 at four sites using capture-recapture of adults and counts of egg masses to examine the dynamics of this metapopulation. Numbers of male toads declined in 1996 and 1999 with annual survival rate averaging 78\% from 1991 to $1994,45 \%$ in 1995 and 3\% between 1998 and 1999. Numbers of egg masses also declined. An etiological diagnosis of chytridiomycosis consistent with infections by the genus Batrachochytrium was made in six wild adult toads. Characteristic histomorphological features (i.e. intracellular location, shape of thalli, presence of discharge tubes and rhizoids) of chytrid organisms, and host tissue response (acanthosis and hyperkeratosis) were observed in individual toads. These characteristics were indistinguishable from previously reported mortality events associated with chytrid fungus. We also observed epizootiological features consistent with mortality events associated with chytrid fungus: an increase in the ratio of female:male toads captured, an apparent spread of mortalities within the metapopulation and mortalities restricted to post metamorphic animals. Eleven years of population data suggest that this metapopulation of toads is in danger of extinction, pathological and epizootiological evidence indicates that $B$. dendrobatidis has played a proximate role in this process

Published by Elsevier Science Ltd.
\end{abstract}

Keywords: Bufo boreas; Colorado; Batrachochytrium dendrobatidis; Chytrid fungus; Amphibian decline

\section{Introduction}

Declines of amphibian species can be characterized under two general patterns: those species that have suffered from well-documented anthropogenic assaults on their habitats, and species for which no obvious causes of declines have been determined. Examples of the first category include both "traditional" endangered species, which tend to be narrowly distributed endemic species (Bury et al., 1980) and more widely distributed species, such as the California red-legged frog (Rana aurora draytoni), endangered because of agricultural and urban

\footnotetext{
* Corresponding author.

E-mail address: erin_muths@usgs.gov (E. Muths).

${ }^{1}$ Present address: University of Illinois Zoological Pathology Program, Loyola University Medical Center Room 0745, Building 101, 2160 South First Street, Maywood, IL 60153, USA.
}

development and the introduction of non-native predators (Hayes and Jennings, 1986; Fisher and Shaffer, 1996). Examples of the latter category include species occurring in relatively undisturbed habitats, such as cloud-forest frogs in Costa Rica (Pounds et al., 1997) and Panama (Lips, 1998), Yosemite toads (Bufo canorus) in California (Kagarise Sherman and Morton 1993), and boreal toads (Bufo boreas boreas) in Colorado (Corn et al., 1989). However, the recent discovery of a pathogenic chytrid fungus (Batrachochytrium dendrobatidis; Longcore et al., 1999; Pessier et al., 1999) associated with declines of frogs in the American and Australian tropics (Berger et al., 1998) and in Spain (Bosch et al., 2001), suggests that the proximate cause, at least, may be assignable for many previously unexplained amphibian declines.

Bufo boreas has been declining in the southern Rocky Mountains of Colorado since the early 1970s (Corn et 
al., 1989; Carey, 1993; Corn, 2000), and the species was listed as endangered by the State of Colorado in 1994. The entire range of Bufo boreas includes much of western North America from northern Baja California to southeastern Alaska (Karlstrom, 1962). However, in the southern Rocky Mountains (southeast Wyoming, Colorado, Utah, southeastern Idaho, and New Mexico) it is restricted to high elevations (2200-3400 m) and may be a different, sibling species to Bufo boreas (Goebel, 1996, Hammerson, 1999). Carey (1993) proposed that suppression of the immune system, in the presence of a pathogen, caused toads to be vulnerable to disease, but no convincing evidence exists for what might be the factor causing immunosuppression. Acid precipitation and increased ultraviolet radiation are two factors that could be localized stressors, but there is no evidence that these factors cause mortality of Bufo boreas embryos in Colorado (Corn and Vertucci, 1992; Vertucci and Corn, 1996, Corn, 1998).

We monitored populations of Bufo boreas in Rocky Mountain National Park (RMNP), Colorado beginning in 1991 (Corn et al. 1997). The objectives of the monitoring were to investigate population processes in a metapopulation of Bufo boreas that had not declined, and to provide RMNP with information on the status of this species and the ecosystem where it occurs. Two persistent and two irregular breeding sites, located within $7 \mathrm{~km}$ of one another, in a single drainage at elevations from 2810 to $3380 \mathrm{~m}$, compose this metapopulation (sensu Hanski and Gilpin, 1997). We have observed migration of adult toads between sites but this drainage is isolated from other habitats potentially occupied by toads by topography. With the exception of an occasional chorus frog (Pseudacris maculata), Bufo boreas, is the only amphibian present in the drainage. In this paper, we report on the catastrophic decline of this metapopulation, coincident with the presence of the chytrid Batrachochytrium dendrobatidis in adult toads.

\section{Methods}

\subsection{Study area}

We studied Bufo boreas within the drainage of the North Fork of the Big Thompson River in the northeastern corner of RMNP, Larimer County, Colorado (Fig. 1). Breeding ponds were embedded in coniferous forest; mainly lodgepole pine (Pinus contorta) at lower elevations changing to Englemann spruce (Picea englemannii) - subalpine fir (Abies lasiocarpa) at higher elevations. Riparian vegetation along streams and around lakes included willow (Salix sp.), bog birch (Betula pumila), sedges (Carex spp.), and grasses.

Bufo boreas bred annually at Kettle Tarn and Lost Lake, and irregularly at Halfway Pond and Lake Hus- ted (Corn et al., 1997; Corn, 1998). Kettle Tarn comprises a glacial kettle pond and an adjoining meadow containing a smaller pool that typically dries each summer. Toads deposited eggs in both bodies of water. Halfway Pond is a small, shallow abandoned beaver pond adjacent to the North Fork about $1 \mathrm{~km}$ west of Kettle Tarn. Lost Lake and Lake Husted (above timberline) are drainage lakes 6.4 and $7.0 \mathrm{~km}$, respectively, west of Kettle Tarn. The drainage above Lost Falls (approximately $4 \mathrm{~km}$ east of Lost Lake) was treated with the piscicide Antimycin in 1986 (Corn et al., 1997, Roselund et al., 2001) to remove non-native fish. Subsequently, endangered greenback cutthroat trout (Oncorhynchus clarki stomias) were reintroduced to both of these lakes. Kettle Tarn and Halfway Pond are fishless.

\subsection{Population estimation}

The primary study sites (Kettle Tarn and Lost Lake) were visited 5-10 times between May and August each year, but Halfway Pond and Lake Husted were surveyed less frequently. Toads were caught by hand from breeding aggregations each year in May and June (Table 2) and from the surrounding habitat during the rest of the summer, including every toad encountered while we moved between sites. We used visual encounter survey techniques (Heyer et al., 1994) at breeding sites. We measured snout-vent length, determined sex and mass, and marked each toad by subcutaneous injection of a uniquely numbered (AVID $\left.{ }^{\circledR}\right)^{2}$ passive integrated transponder (PIT) tag (Corn et al., 1997). Toads were released immediately after processing. We also recorded the number of clutches deposited at each site during breeding. After 1996 we took precautions against inadvertent contamination of breeding sites by us by thoroughly washing and disinfecting all equipment including waders in a $5 \%$ bleach solution.

We estimated survival and population sizes of male Bufo boreas at Kettle Tarn, and Lost Lake using the Jolly-Seber model for open populations (program JOLLY; Pollock et al., 1990) with no assumptions about survival or capture probability. We combined captures of male toads at Halfway Pond, Lake Husted and other terrestrial locations throughout the study area with those marked at Kettle Tarn and Lost Lake to obtain annual estimates of total abundance within the North Fork drainage through 1998 . We used a $Z$ test to evaluate the means and determine $95 \%$ confidence intervals for the estimated population numbers before and after the decline in population was noticed (Ott, 1984).

\footnotetext{
${ }^{2}$ Trade names are provided for information purposes only. No endorsement by the United Stated Geological Survey or the United States Government is intended or implied.
} 


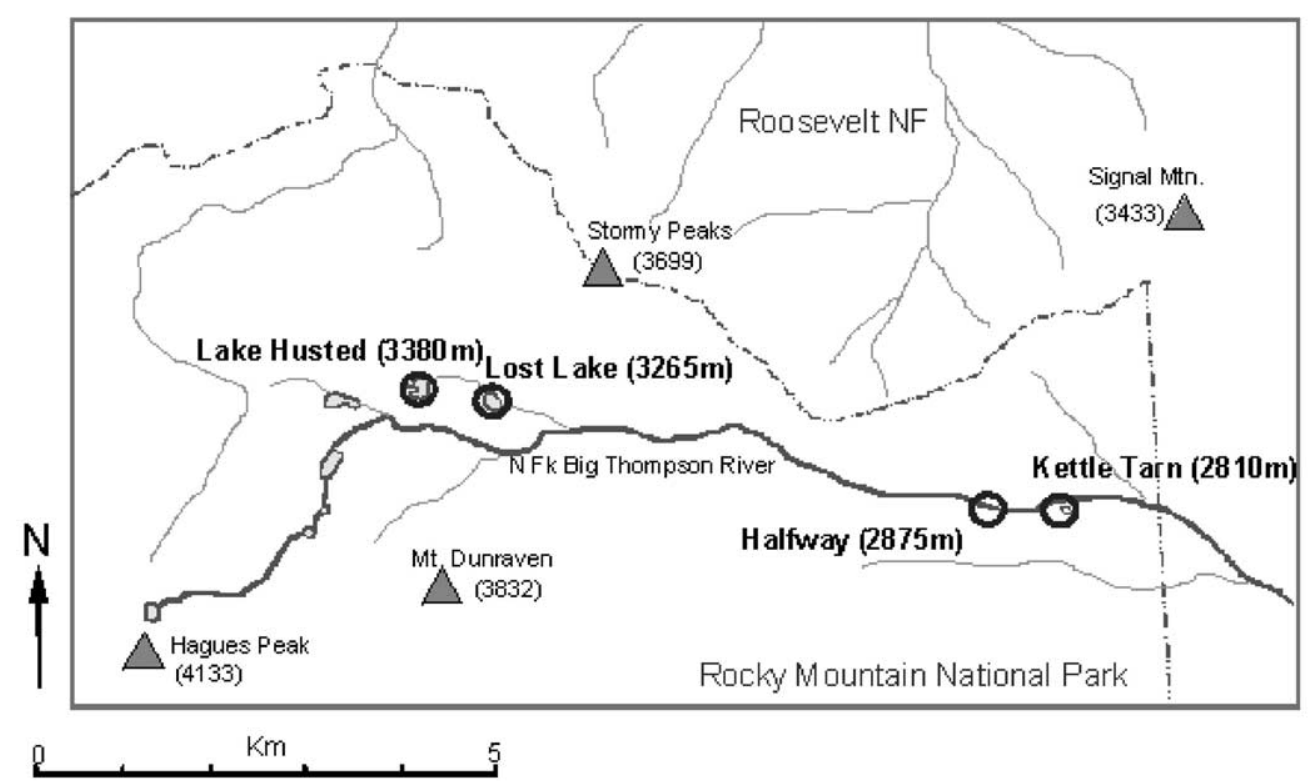

Fig. 1. Locations of study sites in the northeast corner of Rocky Mountain National Park, Colorado. Primary sites are circled and labeled, but boreal toads encountered throughout the drainage were captured and marked.

\subsection{Diagnostic examinations}

Bufo boreas were collected in the field when found dead or when found alive with marked lethargy and sloughing skin. Animals were sent alive or dead and frozen to the diagnostic laboratory. Twelve sick or dead adult toads were collected in $1998(n=4), 1999(n=3)$ and $2000(n=5)$; also, six live tadpoles were collected in 1999 from Lost Lake. Three carcasses from 1998 were examined at the Wyoming State Veterinary Diagnostic Laboratory and held frozen until 1999 when they were examined at the Zoological Society of San Diego. One sample from 1998 and samples from 1999 and 2000 were examined at the US Geological Survey's National Wildlife Health Center (NWHC; Madison, Wisconsin). Select visceral organs or skin of the ventrum (including pelvic patches) and hindlimb digits were fixed in $10 \%$ buffered neutral formalin in the laboratory. Digits were decalcified for $36-48 \mathrm{~h}$ in saturated ethylene diamine tetra-acetic acid (EDTA; SigmaAldrich, St. Louis, Missouri 63178 USA) and then all tissues were processed routinely and embedded in paraffin for sectioning. Sections $(5 \mu \mathrm{m})$ were stained with hematoxylin and eosin and Grocott's methenamine silver (GMS) stains (Luna, 1968). All adult toads collected in 1999 and 3 of 5 collected in 2000 were unsuitable for examination of internal organs or for viral isolation; however sections of skin were obtained for histology. Tissue from three tadpoles and three adults collected in 1999 and 2000 were submitted for virus isolation. Samples were cultured for viruses on fathead minnow and frog tongue fibroblast cell lines. If no cytopathic effect was observed in primary and blind passages, the tissues were considered negative for viruses.

\section{Results}

\subsection{Toad populations}

We observed movements between breeding sites ( $n=24$ between 1994 and 1998, greatest distance approximately $6 \mathrm{~km}$, Corn and Muths personal observation) and conclude that the toads in the North Fork drainage compose a metapopulation (sensu Hanski and Gilpin 1997). Populations of Bufo boreas at Kettle Tarn and Lost Lake were stable or increasing until 1996 (Table 1). We are confident that these population estimates are reasonably accurate, based on high capture probabilities $[P=0.47(\mathrm{SE}=0.03)$ at Lost Lake and $P=0.53(\mathrm{SE}=0.08)$ at Kettle Tarn]. Few females were caught relative to males, and recaptures were rare, so no effort was made to estimate population sizes of females (Table 2).

We observed a large, significant decrease in estimated numbers of male toads at Kettle Tarn after 1995 (1992$1995 ; n=4, \hat{N}=189$, variance $=259.29$, C.I. $=157-220$. Where standard error estimates were available after 1995, confidence intervals did not overlap the C.I.s for previous years $(1996$, C.I. $=0-141 ; 1998$, C.I. $=0-67)$. We observed a smaller, but significant decrease at Lost Lake after $1995(1992-1995 ; n=4, \hat{N}=235$, variance $=112.19$, C.I. $=214-256, \quad 1996-1997 ; n=2, \quad \hat{N}$ $=165$, variance $=145.45$, C.I. $=141-189 ;$ not estimable after 1997). Between 1995 and 1996, the estimated survival rate at Kettle Tarn was $14 \%(\mathrm{SE}=0.12)$, compared to $61 \%(\mathrm{SE}=0.06)$ at Lost Lake (Table 1). Population sizes appeared to stabilize between 1996 and 1998, followed by a second severe decline in 1999, resulting in the near extirpation of Bufo boreas 
Table 1

Estimates of male boreal toads at Kettle Tarn and Lost Lake, Rocky Mountain National Park, Colorado, using the Jolly-Seber full model (no assumptions about survival rate or capture probabilities)

\begin{tabular}{|c|c|c|c|c|c|c|c|c|}
\hline \multirow[t]{2}{*}{ Year } & \multirow[t]{2}{*}{ Captured } & \multirow[t]{2}{*}{ Recaptured } & \multicolumn{2}{|c|}{ Capture probability } & \multicolumn{2}{|c|}{ Population size } & \multicolumn{2}{|c|}{ Survival rate } \\
\hline & & & $P$ & SE & $N$ & SE & $\Phi$ & SE \\
\hline \multicolumn{9}{|c|}{ Kettle Tarn } \\
\hline 1991 & 23 & - & - & & - & & 0.50 & 0.12 \\
\hline 1992 & 63 & 5 & 0.44 & 0.16 & 121 & 39.0 & 1.18 & 0.15 \\
\hline 1993 & 54 & 23 & 0.28 & 0.06 & 187 & 35.0 & 0.61 & 0.08 \\
\hline 1994 & 119 & 39 & 0.56 & 0.07 & 209 & 23.7 & 0.72 & 0.09 \\
\hline 1995 & 211 & 96 & 0.88 & 0.10 & 237 & 29.0 & 0.14 & 0.12 \\
\hline 1996 & 29 & 16 & 0.52 & 0.36 & 54 & 44.7 & 0.03 & 0.03 \\
\hline 1997 & 15 & 2 & $*$ & $*$ & $*$ & $*$ & 0.53 & 0.31 \\
\hline 1998 & 19 & 4 & 0.50 & 0.30 & 32 & 17.8 & 0.21 & 0.09 \\
\hline 1999 & 15 & 5 & $*$ & $*$ & $*$ & $*$ & - & - \\
\hline 2000 & 5 & 2 & - & - & - & - & - & - \\
\hline 2001 & 2 & 2 & $*$ & $*$ & $*$ & $*$ & $*$ & $*$ \\
\hline \multicolumn{9}{|c|}{ Lost Lake } \\
\hline 1991 & 204 & - & - & - & 434 & - & 0.78 & 0.05 \\
\hline 1992 & 143 & 91 & 0.57 & 0.05 & 249 & 18.4 & 0.74 & 0.07 \\
\hline 1993 & 77 & 55 & 0.35 & 0.05 & 217 & 22.1 & 0.80 & 0.08 \\
\hline 1994 & 110 & 66 & 0.46 & 0.05 & 237 & 22.0 & 0.80 & 0.07 \\
\hline 1995 & 122 & 77 & 0.51 & 0.05 & 237 & 22.0 & 0.61 & 0.06 \\
\hline 1996 & 43 & 32 & 0.26 & 0.04 & 161 & 19.2 & 0.94 & 0.08 \\
\hline 1997 & 112 & 82 & 0.66 & 0.06 & 169 & 14.6 & - & - \\
\hline 1998 & 106 & 83 & - & - & - & - & - & - \\
\hline 1999 & 0 & 0 & $*$ & $*$ & $*$ & $*$ & $*$ & $*$ \\
\hline 2000 & 1 & 0 & $*$ & $*$ & $*$ & $*$ & $*$ & $*$ \\
\hline 2001 & 0 & 0 & * & $*$ & * & $*$ & $*$ & * \\
\hline
\end{tabular}

An en-dash (-) indicates parameters not estimated by the model, and an asterisk $\left({ }^{*}\right)$ indicates too few data to estimate parameters.

throughout the North Fork. Small sample sizes in later years resulted in incomplete statistics for individual populations but a single analysis (Fig. 2) of captures of all males in the North Fork drainage present a clear pattern of decline. Survival averaged 78\% $(\mathrm{SE}=0.07)$, from 1991 to 1994 but was $45 \%(\mathrm{SE}=0.06)$, between 1995 and 1996. Survival between 1998 and 1999 was only $3 \%(\mathrm{SE}=0.014)$.
We observed fewer egg masses deposited at breeding sites in the North Fork drainage following declines in male population numbers (Table 2). (Fisher's Least significant difference between 1990-1995 and 1996$1999=-24.75, \quad P=0.001 ; \quad 1996-1999$ and 2000 $2001=-14.250, P=0.062$.) From 1990 to 1995 an average of 44 (range 35-56) egg masses were deposited annually at Lost Lake and Kettle Tarn combined. From

Table 2

Numbers of individual females observed in the North Fork drainage, 1991-2001, minimum numbers of egg masses deposited at Kettle Tarn and Lost Lake, 1990-2001 (egg mass data for 1990-1996 are from Corn et al., 1997) and number of visits during the breeding season (May-June)

\begin{tabular}{|c|c|c|c|c|c|c|c|}
\hline \multirow[t]{2}{*}{ Year } & \multicolumn{3}{|c|}{ Kettle Tarn } & \multicolumn{3}{|c|}{ Lost Lake } & \multirow{2}{*}{$\begin{array}{l}\text { Elsewhere in drainage } \\
\text { Females }\end{array}$} \\
\hline & Females & No. of egg masses & No. of visits & Females & No. of egg masses & No. of visits & \\
\hline 1990 & - & 13 & 1 & - & 22 & 1 & - \\
\hline 1991 & 2 & 23 & 4 & 29 & 15 & 4 & - \\
\hline 1992 & 8 & 18 & 4 & 22 & 23 & 4 & - \\
\hline 1993 & 10 & 25 & 3 & 10 & 13 & 2 & - \\
\hline 1994 & 7 & 21 & 7 & 20 & 35 & 6 & 5 \\
\hline 1995 & 20 & 24 & 9 & 11 & 32 & 5 & 18 \\
\hline 1996 & 13 & 8 & 4 & 3 & 15 & 4 & 6 \\
\hline 1997 & 11 & 8 & 5 & 9 & 15 & 4 & 37 \\
\hline 1998 & 12 & 10 & 5 & 6 & 9 & 4 & 16 \\
\hline 1999 & 5 & 2 & 6 & 6 & 10 & 2 & 1 \\
\hline 2000 & 14 & 4 & 7 & 1 & 3 & 5 & 2 \\
\hline 2001 & 4 & 3 & 4 & 3 & 0 & 3 & 0 \\
\hline
\end{tabular}




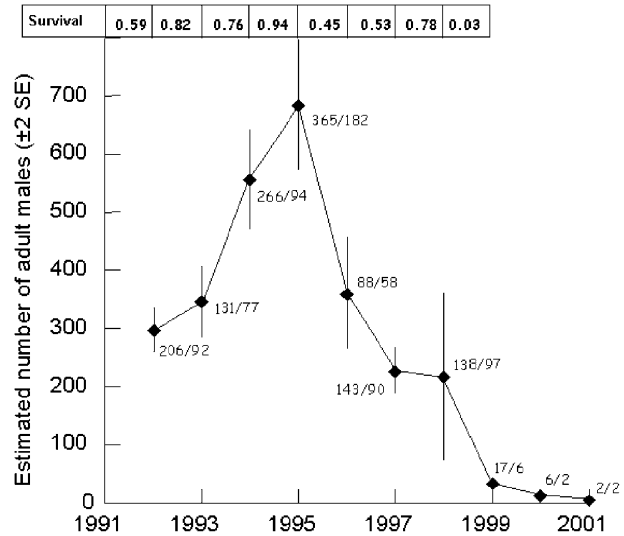

Fig. 2. Estimated number of male boreal toads in the entire North Fork drainage (based on captures at each breeding site as well as incidental captures throughout the drainage). Numbers next to means are number captured/number recaptured, and numbers at top between years are the estimated survival rates. Symbols for 1999-2001 represent total numbers caught divided by the mean capture probability $(0.51)$.

1996 to 1999 , the average total number of egg masses was 19 (range 12-23) and in 2000 and 2001 total egg masses dropped to 7 and 3, respectively. There were no differences in search effort between breeding sites within the drainage between years $P=0.41, F=0.97$ or between years within sites (Kettle: $P=0.90, F=0.10$; Lost: $P=0.94, F=0.07)$. Numbers of females captured, however, do not show the same patterns as males or egg masses. The ratio of female to male captures varied between 0.12 and 0.15 during 1991-1995, increased to 0.25 in 1996 and was 2.8 (17:6) in 2000 (Fig. 3).

\subsection{Necropsy}

On external examination, the three frozen toads from 1998 had moderate amounts of shedding skin of the

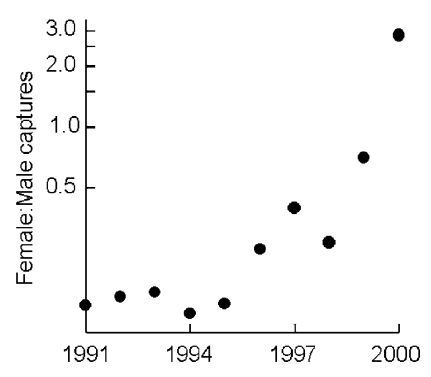

Fig. 3. Semi-log plot of the ratio of female to male boreal toad captures in the North Fork drainage.

abdomen, legs and feet. Although adult toads from 1999 and 2000 had no abnormalities of the skin or internal organs, six were severely desiccated and two were severely autolyzed. A single live adult female toad (collected at Kettle Tarn in 1999) was markedly unresponsive, lethargic, and severely dehydrated (hematocrit: $60.2 \%$ ) despite having been mailed overnight to DEG on a wet substrate following NWHC protocols (Green, D.E., Collection, Preservation \& Mailing of Amphibians for Diagnostic Examinations, Amphibian Research and Monitoring Initiative, Standard Operating Procedure No. 105, Revised, 2 March 2001. http:// www.nwhc.usgs.gov/research/amph_dc/amph_sop.html) the day of capture (Table 3 ). The only gross or histological abnormality in the six tadpoles was two live oxyurid-like nematodes (probably Gyrinicola sp.) in the intestinal lumen of one tadpole.

\subsection{Histology}

Chytridiomycosis was diagnosed in six adult toads with the least autolysis and desiccation (1998, $n=3$; $2000, n=3$ ). In these animals, histologic sections of the skin from the pelvic patch, ventral body and hindlimb

Table 3

Summary of diagnostic findings for 13 boreal toads collected in RMNP

\begin{tabular}{|c|c|c|c|c|c|c|}
\hline \multirow{2}{*}{$\begin{array}{l}\text { Animal } \\
\text { number }\end{array}$} & \multirow{2}{*}{$\begin{array}{l}\text { Capture } \\
\text { year }\end{array}$} & \multirow[t]{2}{*}{ Carcass condition } & \multirow{2}{*}{$\begin{array}{l}\text { Gross } \\
\text { findings }\end{array}$} & \multicolumn{3}{|c|}{ Histological findings } \\
\hline & & & & $\begin{array}{l}\text { Hyper- } \\
\text { keratosis }\end{array}$ & $\begin{array}{l}\text { Chytrid } \\
\text { Zoosporangia }\end{array}$ & $\begin{array}{l}\text { Post-mortem } \\
\text { fungal hyphae }\end{array}$ \\
\hline 11515 & 1998 & Frozen & Dysecdysis & + & + & + \\
\hline 11516 & 1998 & Frozen & Dysecdysis & + & + & + \\
\hline 11517 & 1998 & Frozen & Dysecdysis & + & + & + \\
\hline $16380-2$ & 1998 & Desiccated & Dry fly pupae & + & $0(?)^{* *}$ & + \\
\hline $16380-9$ & 1999 & Decomposed in stream & Advanced decomposition & ND & ND & + \\
\hline $16380-10$ & 1999 & Desiccated & Desiccation & + & $0(+)^{*}$ & + \\
\hline $16380-1$ & 1999 & Desiccated & Desiccation & + & $0(+)^{*}$ & + \\
\hline $16833-1$ & 2000 & Desiccated & Desiccation & + & $0(+)^{*}$ & 0 \\
\hline $16833-2$ & 2000 & Live, sick & Dysecdysis, Dehydration & + & $+(+)^{*}$ & 0 \\
\hline $16833-3$ & 2000 & Desiccated & Desiccation & + & $0(+)^{*}$ & 0 \\
\hline $16874-1$ & 2000 & Desiccated & Fly eggs, desiccation & + & $+(+)^{*}$ & 0 \\
\hline $16874-2$ & 2000 & Decomposed in stream & Advanced decomposition & + & $+(+)^{*}$ & 0 \\
\hline
\end{tabular}

$\mathrm{ND}=$ not determined. One asterisk $(*)$ indicates preliminary molecular evidence for the presence of chytrid fungus, two asterisks $(* *)$ indicate that the preliminary molecular evidence is equivocal. 


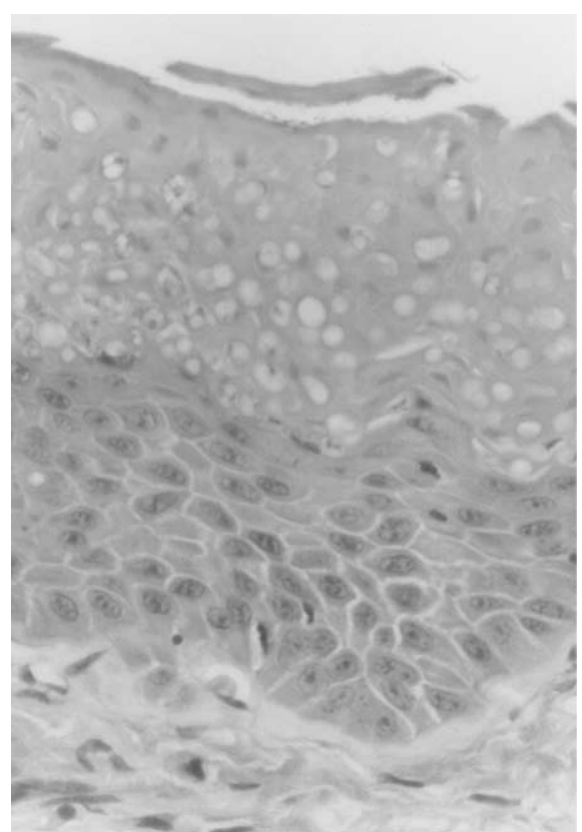

Fig. 4. Adult female Bufo boreas, skin of pelvic patch. The bottom of the figure is dermis and the top region is keratinized epidermis. Marked hyperkeratosis and myriads of clear (empty) circular chytridial thalli are present in the stratum corneum; all chytridial thalli have discharged their zoospores. There also is mild acanthosis (thickening of the stratum spinosum and stratum granulosum) and typical absence of inflammatory cells in the dermis and epidermis. Hematoxylin and eosin, $\times 400$.

digits showed host tissue response of moderate epidermal thickening in three layers of the epidermis (acanthosis = thickening of the stratum spinosum and stratum granulosum and orthokeratotic hyperkeratosis $=$ thickening of the outermost, keratinized, stratum corneum). (Fig. 4). There were myriad chytrid fungal thalli within the cells of the keratinized layer as have been described previously (Berger et al. 1998; Pessier et al. 1999, Green and Kargarise Sherman, 2001). There was no inflammatory cell response in the underlying dermis or around dermal capillaries.

The chytrid thalli identified in the tissue were spherical to slightly ovoid, 6-16 microns in diameter and were located only within the keratinized cells of the thickened stratum corneum. Occasional thalli had one or two septae (colonial thalli) which are highly consistent with Batrachochytrium sp. (Longcore et al. 1999). A few of the thalli had a single tubular extension (discharge papilla) that was directed towards the epidermal surface. Most thalli were empty, but some contained 1 to $>8$ basophilic, 1-2 micron diameter zoospores. Thalli were positive with GMS stain and fine, thread- or rootlike branching extensions (rhizoids) were observed to extend into deeper portions of the epidermis (Fig. 5). In toads that were frozen or chilled, bacteria were present on the epidermal surface and within some thalli. In addition, some autolyzed toads had rare septate fungal

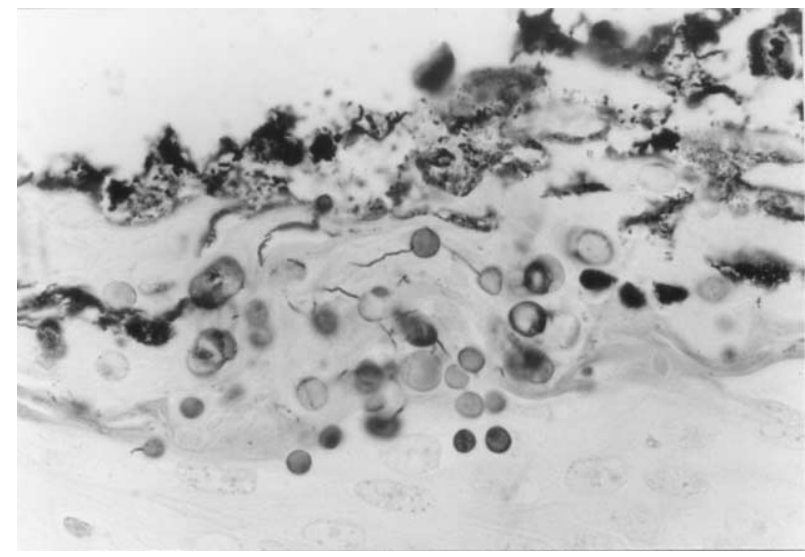

Fig. 5. Adult female Bufo boreas, skin of pelvic patch. Superficial epidermis shows moderate hyperkeratosis and numerous chytridial thalli. Chytrids are circular and grey to black. Several chytridial thalli have long thin black filaments typical of rhizoids. Rhizoids are not visible in H\&E-stained material (Fig. 4). Black debris on the surface of the epidermis is bacteria. Warthin-Starry stain, $\times 600$ (oil immersion).

hyphae, not visibly connected to thalli, within the epidermis and superficial dermis.

In 3 of 6 severely desiccated carcasses, moderate hyperplasia and hyperkeratosis was noted in the epidermis of the pelvic patch and ventral abdomen. While these conditions are characteristic of chytrid infection, no spherical thalli were detected in these dried specimens so the diagnosis remains equivocal in these cases from 1999 .

Four tadpoles were examined histologically and two were submitted whole for virus cultures. No histological evidence of chytrid fungi was detected in the keratinized parts of the oral discs and there was no evidence of inflammation or organisms in the skin, oral discs and visceral organs of the tadpoles. Cultures for viruses were negative for tadpoles and adult toads.

\section{Discussion}

\subsection{Pathology}

The morphology of the fungal organisms, their tissue tropism and host tissue response in the sick and dead adult Bufo boreas from RMNP are characteristic features of chytrid fungal infections by Batrachochytrium dendrobatidis (Berger et al., 1998; Pessier et al., 1999; Longcore et al. 1999). The epidermal bacteria and septate fungal hyphae that were observed in a few toads are interpreted as secondary or decompositional invaders. In our experience (DEG and APP), such secondary colonization is not uncommon in cases of chytridiomycosis, presumptively because the increased surface area created by excess surface keratin layers (hyperkeratosis) and empty chytrid zoosporangia trap and favor the growth of these organisms. The presence 
of the pathogenic chytrid fungus in the epidermis of every adequately preserved sick and dead adult boreal toad ( $n=6$ ) from RMNP at the same time that striking population declines were observed in this metapopulation is consistent with previously reported chytrid epizootics in amphibians in Costa Rica, Panama and Australia (Lips, 1998; Berger et al. 1998). Furthermore, the degree of hyperkeratosis and epidermal thickening was of a magnitude consistent with that observed in both naturally occurring and experimentally induced fatal cases of amphibian chytridiomycosis (Berger et al., 1998; Pessier et al., 1999; Nichols et al., 2001).

Preliminary molecular evidence indicated the presence of chytrid fungus in 7 of 8 of the animals submitted, and one equivocal result ( $\mathrm{J}$. Wimsatt personal communication; Table 3). Combining the histological and preliminary molecular evidence, a majority of the animals collected (10 of 12) were positive for chytrid fungus. Of the remaining two animals, one was decomposed beyond analysis (animal number 16380-9) and one resulted in a negative histological examination but was deemed "equivocal" using molecular techniques (animal number 16380-2).

Finally, histologic examination and limited virus isolation identified no other diseases. These lines of evidence provide support that chytridiomycosis was the probable cause of death in examined animals and we conclude that post-metamorphic chytrid fungus infection is the likely proximate cause of recent population declines in this metapopulation.

\subsection{Alternative diagnoses}

In the southern and central Rocky Mountains another fungal skin infection, basidiobolomycosis, has been reported in Bufo boreas, captive Canadian toads (Bufo hemiophrys), and in wild, re-introduced and captive Wyoming toads (B. baxteri; Taylor et al. 1999a, 1999b; M. Jennings, personal communication). In toads from $1998(n=3)$, the fungi within the skin were initially identified histologically as Basidiobolus ranarum. Our subsequent histologic examination (Table 3) revealed that all of the 1998 toads had fungal elements in their skin consistent with chytridiomycosis and the diagnosis was revised. At present, it is not clear whether basidiobolomycosis (infection by Basidiobolus ranarum), is a primary cause of dermomycosis in bufonids, a fecal contaminant of chytrid-infected skin, or a secondary or opportunistic invader. Because histologic features of chytridiomycosis and basidiobolomycosis in anurans appear to be similar (Groff et al., 1991; Berger et al., 1998; Carey et al., 1999; Pessier et al., 1999, Taylor et al., 1999a, Green and Kagarise Sherman, 2001), a review of other cases of anuran basidiobolomycosis may be warranted. Features of Basidiobolus infection that could mimic chytridiomycosis include (1) extension of germ tubes from globose conidia that may resemble discharge papillae of chytrids, (2) formation of internal septae in balistosporic conidia that could resemble the septae of colonial chytrid thalli, and (3) tissue tropism (keratinophilia) and selective tropism (preference for epidermis of the ventrum and digits; Drechsler, 1956; Dykstra, 1994). Features that distinguish the two fungi and are considered characteristic of Batrachochytrium infection are threefold: (1) the presence of 1-2 micron diameter zoospores within the chytrid thalli, (2) absence of characteristic hyphae of Basidiobolus in fresh epidermal tissue, and (3) the presence of fine, thread-like branching rhizoids from chytrid thalli (Longcore et al., 1999). We maintain that the observed hyphae in the epidermis and, more importantly, invading the dermis of some autolyzed toads in this study were secondary invaders and decompositional water molds.

\subsection{Decline of $\mathrm{B}$. boreas in the Southern Rocky Mountains}

Remnant populations of $B$. boreas, such as the metapopulation in the North Fork, remained after the widespread population declines in Colorado in the 1970s and 1980s (Carey, 1993). Recently, extensive population declines commensurate with identified chytrid fungal infections have been observed at another location in Colorado, in addition to the North Fork (D.E. Green, personal observation; Loeffler 2001) and known breeding populations of Bufo boreas now number fewer than 30 (Loeffler, 2001). In 2000, only six populations of Bufo boreas in Colorado were considered viable (Loeffler, 2001). After fungal infection was diagnosed in the Wyoming toad (Taylor et al., 1994) we were vigilant for signs of disease in boreal toads in the North Fork drainage. Nothing out of the ordinary was found until we collected the animals reported in this study.

Infection by chytrid fungus has a lethal effect on anurans (Green and Kargarise Sherman, 2001; Nichols et al., 2001). Infected frogs in captivity die within 3 wks (Berger et al., 1998) and current research indicates that infected toads in the wild are also dying (Bosch et al., 2001). This disease is highly contagious (Nichols et al., 2001) with motile, waterborne zoospores (Longcore et al., 1999) and boreal toads congregate in small water bodies to breed (Hammerson, 1999). If the chytrid epizootic does not extirpate these remnant populations in the southern Rocky Mountains, stochastic events that affect mortality and recruitment may (e.g. Carey et al., in press). Such factors include the unpredictable and often severe weather that occurs at high elevations in Colorado, this affects the success of egg deposition and recruitment such that it varies greatly from year to year. Predation by raccoons, foxes and corvids on post metamorphic toads has been documented (Beiswenger, 1981; Olson, 1989; Corn, 1993; Jones et al., 1999). 
Eviscerated carcasses of adult toads have been found in recent years at Kettle Tarn (Corn, 1993) and sandpipers (Actitis macularia) have been observed eating tadpoles along the shore of Lost Lake.

There may be other potential causes of the decline of toads in the North Fork drainage. Climate change has been evaluated as a potential contributor to the decline of amphibians (e.g. Kiesecker et al., 2001; Pounds et al., 1997). At our location, extremes such as drought conditions did not occur during the study. Water quality parameters such as $\mathrm{pH}$, conductivity and basic ion chemistry, have not changed (Corn and Muths personal observation). UV-B radiation, has been shown to be detrimental to eggs of Bufo boreas in Oregon (Blaustein et al. 1998). However, our experiments in 1994-1996 conducted in Colorado and surrounding western states concluded that UV-B did not affect hatching success of boreal toad eggs (Corn, 1998; Corn and Muths, personal observation). Furthermore, natural levels of UV-B radiation have not been reported to cause mortality in post metamorphic amphibians. Corn and Vertucci (1992) and Vertucci and Corn (1996) reported that episodic acidification of surface waters in the mountains of Colorado did not affect hatching success of Bufo boreas or other species of amphibians. However, sublethal effects of these potential stressors, including their effects on immunosuppression, have not been studied (Carey et al., 1999).

Mass mortalities of Bufo boreas occurred in the 1970s in the West Elk Mountains of Colorado (Carey, 1993; Carey et al., in press). These deaths were attributed to an unknown environmental factor causing stress to the animal, followed by immunosuppression and infection by Aeromonas hydrophila (Carey, 1993). A northern leopard frog (Rana pipiens) was collected (41 km north of Kettle Tarn) and preserved in 1974 (by PSC). This animal was recently examined histologically and found to have chytrid fungus infection (DEG and C. Carey personal communication). Because this individual was held in captivity prior to preservation, this case provides only equivocal evidence about the presence of chytridiomycosis in wild anuran populations in the 1970s. However, this animal establishes the geographical presence of the pathogenic chytrid fungus as early as 1974 in Colorado (Carey et al., 1999).

The decline of Bufo boreas in the North Fork drainage of Rocky Mountain National Park has the same epizootiological features of chytrid-induced amphibian population declines in Australia and Central America (Berger et al. 1998) and Bufo canorus in the Sierra Nevada of California (Green and Kagarise Sherman, 2001). The North Fork population decline also shares many of the epizootiological features of a post metamorphic death syndrome of anurans in the southwestern US (Scott, 1993). Population declines in the North Fork were sudden and severe with males disappearing first and no mortality in tadpoles.
Batrachochytrium is transmitted via a motile, spermatozoa-shaped, aquatic zoospore (Berger et al., 1998; Pessier et al., 1999; Nichols et al., 2001). Male toads congregate at breeding sites in the early spring and remain there for the duration of the breeding season. In contrast, females may breed only every second to fourth year (Carey et al., in press) and are transient visitors to breeding sites. These behaviors suggest that male toads experience a longer potential exposure to the pathogenic chytrid fungus than do females. The rapidly increasing ratio of female to male captures after 1996 (Fig. 3) supports this interpretation. A similar shift has been documented in another declining species, Atelopus chiriquiensis (Lips, 1998).

We believe that chytridiomycosis in Bufo boreas in the North Fork is a serious threat to the survival of this remnant metapopulation. Any management activity designed to avert this must use adequate quarantine procedures. Factors involved in animal to animal transmission, geographic dissemination of the fungus, host susceptibility, chytrid pathogenicity, and possible chytrid strain variations are poorly understood and additional research efforts to control this contagious and lethal amphibian disease are necessary.

\section{Acknowledgements}

Thanks to A. Goebel, A. Davidson, J. Kiesecker, M. Jennings, L. Livo, S. Winkler, C. Wilks, S. Zwicker, B. Johnson, S. Rittmann, and C. Lyons for help in the field and especially to R. Scherer for help in the field and discussions of various aspects of the project. Many thanks to J. Wimsatt for sharing information and preliminary molecular data. Thanks to R.B. Bury, C. Carey, T. Fritts, K. Lips, J. E. Longcore, J. Longcore, and B. Noon for commenting on the manuscript and to M. Conner for statistical advice. Also thanks to M. Jones for facilitating examination of 1998 toads and to E. Williams and S. Taylor for storage of 1998 material and diagnostic evaluations.

\section{References}

Berger, L., Speare, R., Daszak, P., Green, D.E., Cunningham, A.A., Goggin, C.L., Slocombe, R., Ragan, M.A., Hyatt, A.D., McDonald, K.R., Hines, H.B., Lips, K.R., Marantelli, G., Parkes, H., 1998. Chytridiomycosis causes amphibian mortality associated with population declines in the rain forests of Australia and Central America. Proceedings of the National Academy of Science USA 95, 9031-9036.

Beiswenger, R.E., 1981. Predation by gray jays on aggregating tadpoles of the boreal toad (Bufo boreas). Copeia 459-460.

Blaustein, A.R., Kiesecker, J.M., Chivers, D.P., Hokit, D.G., Marco, A., Belden, L.K., Hatch, A., 1998. Effects of ultraviolet radiation on amphibians: field experiments. American Zoologist 38, 799-812.

Bosch, J., Martinez-Solano, I., Garcia-Paris, M., 2001. Evidence of a chytrid fungus infection involved of the decline of the common 
midwife toad (Alytes obstetricans) in protected areas in central Spain. Biological Conservation 97, 331-337.

Bury, R.B., Dodd Jr., C.K., Fellers, G.M., 1980. Conservation of the amphibia of the United States. USDI Fish and Wildlife Service Resource Publication 134, Washington, DC.

Carey, C., 1993. Hypothesis concerning the causes of the disappearance of $B$. boreas from the mountains of Colorado. Conservation Biology 7, 355-362.

Carey, C., Cohen, N., Rollins-Smith, L., 1999. Amphibian declines: an immunological perspective. Developmental and Comparative Immunologyy 23, 459-472.

Carey, C., Corn, P.S., Jones, M.S., Livo, L.J., Muths, E., Loeffler, C.W., in. Environmental and life history factors that limit recovery in southern rocky mountain populations of boreal toads (Bufo boreas). In: Lannoo, M. (Ed.), Status and Conservation of U.S. Amphibians. pressUniversity of California Press, Berkeley.

Corn, P.S., 1993. Bufo boreas (boreal toad) predation. Herpetological Review 24, 57.

Corn, P.S., 1998. Effects ultraviolet radiation on boreal toads in Colorado. Ecological Applications 8, 18-26.

Corn, P.S., 2000. Amphibian declines: review of some current hypotheses. In: Sparling, D.W., Linder, G., Bishop, C.A. (Eds.), Ecotoxicology of Amphibians and Reptiles. Setac Press, Pensacola, Florida, pp. 663-696.

Corn, P.S., Stolzenburg, W., Bury, R.B., 1989. Acid Precipitation Studies in Colorado and Wyoming: Interim Report of Surveys of Montane Amphibians and Water Chemistry. USDI Fish and Wildlife Service Biological Report 80(40.26), Washington, DC.

Corn, P.S., Vertucci, F.A., 1992. Descriptive risk assessment of the effects of acidic deposition on Rocky Mountain amphibians. Journal of Herpetology 26, 361-369.

Corn, P.S., Jennings, M.L., Muths, E., 1997. Survey and assessment of amphibian populations in Rocky Mountain National Park. Northwestern Naturalist 78, 34-55.

Drechsler, C., 1956. Supplementary developmental stages of Basidiobolus ranarum and Basidiobolus haptosporus. Mycologia 48, 655676.

Dykstra, M.J., 1994. Ballistosporic conidia in Basidiobolus ranarum: The influence of light and nutrition on the production of conidia and endospores (sporangiospores). Mycologia 86, 494-501.

Fisher, R.N., Shaffer, H.B., 1996. The decline of amphibians in California's Great Central Valley. Conservation Biology 10, 1387-1397.

Goebel, A.M., 1996. Systematics and Conservation of Bufonids in North America and in the Bufo boreas Species Group. PhD Dissertation, University of Colorado, Boulder.

Green, D.E., Kagarise Sherman, C., 2001. Diagnostic histological findings in Yosemite toads (Bufo canorus) from a die-off in the 1970's. Journal of Herpetology 35, 92-103.

Groff, J.M., Mughannam, A., McDowell, T.S., Wong, A., Dykstra, M.J., Frye, F.L., Hedrick, R.P., 1991. An epizootic of cutaneous zygomycosis in cultured dwarf African clawed frogs (Hymenochirus curtipes) due to Basidiobolus ranarum. Journal of Medical and Veterinary Mycology 29, 215-223.

Hammerson, G.A., 1999. Amphibians and Reptiles in Colorado. University Press of Colorado, Niwot, CO and Colorado Division of Wildlife.

Hanski, I.A., Gilpin, M., 1997. Metapopulation Dynamics: Ecology, Genetics and Evolution. Academic Press, New York.

Hayes, M.P., Jennings, M.R., 1986. Decline of ranid frog species in western North America: are bullfrogs (Rana catesbeiana) responsible? Journal of Herpetology 20, 490-509.

Heyer, W.R., Donnelly, M.A., McDiarmid, R.W., Hayek, L.C., Fos- ter, M.S., 1994. Measuring and Monitoring Biological Diversity Standard Methods for Amphibians. Smithsonian Institution Press, Washington.

Jones, M., Goettl, J.P., Livo, L., 1999. Bufo boreas (boreal toad) predation. Herpetological Review 30, 91.

Kagarise Sherman, C., Morton, M.L., 1993. Population declines of Yosemite toads in the eastern Sierra Nevada of California. Journal of Herpetology 27, 186-198.

Karlstrom, E.L., 1962. The toad genus Bufo in the Sierra Nevada of California: ecological and systematic relationships. University of California Publications in Zoology 62, 1-104.

Kiesecker, J.M., Blaustein, A.R., Belden, L.K., 2001. Complex causes of amphibian population declines. Nature 410, 681-684.

Lips, K., 1998. Decline of a tropical montane amphibian fauna. Conservation Biology 12, 106-117.

Loeffler, C., 2001. Conservation Plan and Agreement for the Management and Recovery of the Southern Rocky Mountain Population of the Boreal Toad (Bufo boreas boreas). Colorado Division of Wildlife, Denver, Colorado.

Longcore, J.E., Pessier, A.P., Nichols, D.K., 1999. Batrachochytrium dendrobatidis gen. et sp. nov., a chytrid pathogenic to amphibians. Mycologia 91, 219-227.

Luna, L.G., 1968. Manual of Histologic Staining Methods of the Armed Forces Institute of Pathology, third ed. McGraw-Hill Book Company, New York.

Nichols, D.K., Lamirande, E.W., Pessier, A.P., Longcore, J.E., 2001. Experimental transmission of cutaneous chytridiomycosis in dendrobatid frogs. Journal of Wildlife Diseases 37, 1-11.

Olson, D.H., 1989. Predation on breeding western toads (Bufo boreas). Copeia 2, 391-397.

Ott, L., 1984. An Introduction to Statistical Methods and Data Analysis, Second ed. Duxbury Press, Boston.

Pessier, A.P., Nichols, D.K., Longcore, J.E., Fuller, M.S., 1999. Cutaneous chytridiomycosis in poison dart frogs (Dendrobates spp) and White's tree frogs (Litoria caerulea). Journal of Veterinary Diagnostic Investigation 11, 194-199.

Pollock, K.H., Nichols, J.D., Brownie, C., Hines, J.E., 1990. Statistical inference for capture-recapture experiments. Wildlife Monographs 107.

Pounds, J.A., Fogden, M.P., Savage, J.M., Gorman, G.C., 1997. Tests of null models for amphibian declines on a tropical mountain. Conservation Biology 11, 1307-1322.

Rosenlund, B.D., Kennedy, C., Czarnowski, K. 2001. Fisheries and Aquatic Management, Rocky Mountain National Park. Colorado Fish and Wildlife Assistance Office. 201 pp. + appendices.

Scott, N.J., 1993. Postmetamorphic death syndrome. FrogLog 7, 1-2. Taylor, S.K., Williams, E.S., Mills K., Boerger-Fields, A., Thorne E.T., Kwiatkowski, D.R., Anderson, S.L., Burton, M.S., 1994. The Wyoming toad (Bufo hemiophrys baxteri): a review of causes of mortality in the captive population. Proceedings of the Association of Reptilian and Amphibian Veterinarians and American Association of Zoo Veterinarians, Baer, C.K. (Ed.). American Association of Zoo Veterinarians, Media, PA. pp. 73-75.

Taylor, S.L., Williams, E.S., Thorne, E.T., Mills, K.W., Withers, D.I., Pier, A.C., 1999. Causes of mortality of the Wyoming toad. Journal of Wildlife Diseases 35, 49-57.

Taylor, S.L., Williams, E.S., Mills, K.W., 1999. Experimental exposure of Canadian toads to Basidiobolus ranarum. Journal of Wildlife Diseases 35, 58-63.

Vertucci, F.A., Corn, P.S., 1996. Evaluation of episodic acidification and amphibian declines in the Rocky Mountains. Ecological Applications $6,449-457$. 